\title{
EL LIBERAL, DE SEVILLA (1901-1936). UN DIARIO INDEPENDIENTE EN LA ANDALUCÍA ANTERIOR A LA GUERRA CIVIL
}

\author{
Leandro Álvarez Rey y María del Carmen Fernández Albéndiz
}

A diferencia de otros grandes diarios publicados en Andalucía a lo largo de su historia, cuyo estudio en profundidad apenas ha suscitado el interés que el tema merece, las vicisitudes de El Liberal de Sevilla son hoy relativamente conocidas por un hecho sin duda excepcional: la existencia de unas Memorias redactadas por quien fue su director durante veintisiete años, José Laguillo Bonilla, dadas a conocer en 1979 por Alfonso Braojos. ${ }^{1}$ El Liberal, un periódico fundado el 6 de enero de 1901 y que continuó publicándose de forma ininterrumpida hasta el 18 de julio de 1936, se distinguió siempre por su carácter independiente, si bien en sus últimos meses de existencia, durante la etapa del Frente Popular, decidió titularse como «Diario republicano de información». Recién iniciada la sublevación militar, la sede de El Liberal fue asaltada por las fuerzas al mando de Queipo de Llano, quienes se incautaron del mismo imprimiéndose meses después en sus talleres el diario FE, órgano de Falange Española en Sevilla durante los años cuarenta e integrante de lo que pasaría a llamarse la cadena de «Medios de Comunicación Social del Estado», más conocida popularmente como la Prensa del Movimiento. ${ }^{2}$

1. Véase Laguillo, José, Memorias. Veintisiete años en la dirección de «El Liberal» de Sevilla (1907-1936), Sevilla, Universidad, 1979 (introducción y notas por Alfonso Braojos Garrido), 370 páginas.

2. Todas las publicaciones pertenecientes a la empresa de la que dependía El Liberal de Sevilla fueron incautadas por el Estado franquista sin indemnización, como recordaba a comienzos de los años ochenta uno de los herederos de los antiguos propietarios. Véase Busquets le Monnier, Guillermo, «La Prensa del ex Movimiento», El País, Madrid, 28-11981. 
La reciente reorganización de los fondos del conocido como Archivo de Salamanca (actualmente denominado Centro Documental de la Memoria Histórica), lugar al que fue a parar ya desde 1937 la ingente documentación fruto del expolio al que fueron sometidas las organizaciones, partidos, empresas y personas particulares desafectas al «Glorioso Movimiento», ha permitido que salgan a la luz parte de aquellos papeles incautados tras el violento asalto que padeció la redacción y oficinas de El Liberal. Se trata de una documentación de gran interés, correspondiente sobre todo a los años veinte y treinta y que incluye desde las nóminas que cobraban todas las personas que trabajaban para el diario (periodistas, redactores, administradores, oficinistas, personal de talleres, repartidores, etc.); las hojas de contabilidad de la empresa, la distribución detallada del diario y la correspondencia mantenida durante varios años entre el gerente de El Liberal en Sevilla y los responsables de su empresa editora en Madrid. En suma, una documentación que nos permite conocer los entresijos y la vicisitudes de este gran diario más allá de los recuerdos de quien fuera su director -José Laguillo-, cuyo testimonio, parcial y subjetivo, ha pesado quizás en demasía a la hora de comprender y valorar lo que realmente representó El Liberal entre los medios de comunicación y la opinión pública andaluza anterior a la Guerra Civil. Con esta nueva perspectiva hemos abordado, pues, este intento de síntesis de lo que fue la historia de El Liberal de Sevilla.

\section{Orígenes y primeros años de El Liberal de Sevilla}

Como escribieron en su día María Cruz Seoane y María Dolores Sáiz, el origen de la empresa de El Liberal se remonta al año 1879, cuando un grupo de periodistas de ideología republicana decidieron abandonar la redacción de El Imparcial, al declararse este diario partidario de la Monarquía borbónica restaurada tras el pronunciamiento de Martínez Campos. Bajo la dirección de Isidoro Fernández Flores, Miguel Moya y Antonio Sacristán, El Liberal de Madrid se convirtió rápidamente en uno de los principales diarios de finales del siglo XIX, periódico popular y órgano de expresión del republicanismo «gubernamental» y moderado, iniciando a partir del nuevo siglo una fuerte expansión que le llevaría a crear, entre 1901 y 1902, una cadena de periódicos en provincias. A ella pertenecieron El Liberal de Sevilla y los diarios que con idéntico título comenzaron a publicarse en Barcelona, Bilbao y Murcia. Este trust de prensa pasó a depender desde 1907 de la Sociedad Editorial de España, cuyo consejo de administración presidió desde su constitución Miguel Moya y Ojanguren, diputado republicano a Cortes desde 1886 a 1919, fundador y presidente desde 1895 de la Asociación de la Prensa de Madrid y a quien las autoras citadas califican de «figura patriarcal en 
la prensa madrileña». ${ }^{3}$ Con el paso de los años y antes de su desaparición a comienzos de la década de los veinte, la Sociedad Editorial de España dirigida por Moya llegaría a hacerse con el control de casi una decena de diarios, entre los que figuraron El Liberal de Madrid, El Heraldo y El Imparcial, publicados también en la capital de España; El Defensor de Granada, El Noroeste, de Gijón, además de los periódicos que con la cabecera y título de El Liberal continuaron editándose en Sevilla, Barcelona, Bilbao y Murcia. ${ }^{4}$

En 1901, año en que apareció publicado el primer ejemplar de El Liberal, en Sevilla existían nada menos que diez diarios locales, algunos de los cuales venían editándose desde mediados del siglo XIX. ${ }^{5}$ Sevilla, por tanto, a comienzos del nuevo siglo, no parecía ser el lugar más idóneo para que prosperase una nueva empresa periodística, aunque esta viniese avalada por el pujante trust de prensa de Moya. De hecho, en sus primeros años El Liberal, cuyos talleres se instalaron en un local situado en la calle García de Vinuesa, n. ${ }^{\circ}$ 30, no pasó de ser un muy modesto periódico de provincias, de escasa circulación, de cuatro páginas compuestas a seis columnas y de un formato de 44 x 58 centímetros.

No obstante, la redacción que integró aquel primer diario sí constituía un grupo de profesionales de calidad, formada por periodistas como José García Orejuela, Manuel Chaves Rey, Muñoz San Román, Antonio Reyes, Emilio Gierts, Diógenes Ferrand, Francisco Andrade, Alfredo Carmona, Escobar, Piñal, etc., algunos de los cuales permanecerían vinculados al periódico durante muchos años. Para el lanzamiento de El Liberal Moya escogió también como director a

3. Sobre la constitución y trayectoria en sus primeros años de El Liberal de Madrid, véase especialmente SeoAne, María Cruz y SÁiz, María Dolores, Historia del periodismo en España. El siglo XX: 1898-1936, Madrid, Alianza Editorial, 1998 (1. ${ }^{a}$ ed., 1996), en especial pp. 73-80. Miguel Moya fue diputado a Cortes por Puerto Rico en 1886, 1891 y 1898; por Cuba en 1893 y 1898 y por Huesca en diez ocasiones, desde 1899 a 1919.

4. Véase Seoane, M. C. y Sáz, M. D., Historia del periodismo, op. cit..., lugar citado y Gómez Aparicio, Pedro, Historia del Periodismo Español. De las guerras coloniales a la Dictadura, Madrid, Editora Nacional, 1974, pp. 243 y ss.

5. Estos periódicos eran El Porvenir, «diario político independiente» publicado entre 18481909. Afines al Partido Liberal eran El Heraldo Sevillano (1877-1916); El Progreso (18831907); La Andalucía Moderna (1888-1911) y La Iberia (1901-1902). Como único órgano de expresión de los conservadores se publicaba el diario Sevilla (1897-1916), continuador de La Región y La Monarquía. Por su parte El Baluarte, diario republicano entre 1886 y 1903, se siguió publicando pero ya como semanario hasta 1908. La prensa más conservadora estaba representada por el católico El Correo de Andalucía, órgano del Arzobispado y cuyo primer número data de febrero de 1899. Finalmente, como «diario independiente» se editaba El Noticiero Sevillano, diario de Peris Mencheta fundado en marzo de 1893 y al cual le había brotado a la altura de 1901 un vástago de corta vida: El Noticiero Obrero, editado entre marzo y septiembre de 1901 por la Asociación de Obreros del Arte de Imprimir. 
un excelente periodista, aunque como tantos otros hoy día su nombre resulte prácticamente desconocido. El elegido fue José Nogales Nogales, nacido en Valverde del Camino (Huelva) en 1860. Hijo de notario y licenciado en Derecho por la Universidad de Sevilla, donde en su etapa como estudiante colaboró en El Látigo y El Pensamiento Moderno, José Nogales fue siempre un hombre muy preocupado por los problemas sociales y de claras simpatías republicanas. Director de La Coalición Republicana y del diario La Provincia, fundador de La Rana y colaborador de periódicos como La Concordia, El Alcance y Diario de Huelva, fueron las crónicas de José Nogales las que dieron a conocer a la opinión pública los aspectos más sórdidos de la terrible matanza que las autoridades de la época llevaron a cabo en 1888 en Riotinto. Sus denuncias le valieron ser perseguido y granjearse, por decisión de los caciques de entonces, el ostracismo en su Huelva natal. Funcionario de la Diputación onubense y escritor por afición, en 1900 ganó un certamen literario convocado por El Liberal de Madrid con un cuento de temática social y regeneracionista, titulado Las tres cosas del Tío Juan, que le hizo alcanzar rápidamente una notable fama y popularidad. Fichado por Moya, Nogales sólo permaneció al frente de El Liberal de Sevilla durante medio año, tras ser reclamado para integrarse definitivamente en la redacción del periódico en Madrid. ${ }^{6}$ Amigo personal de Méndez Bejarano, de Blasco Ibáñez y de Benito Pérez Galdós, José Nogales, a pesar de su temprana muerte, ejerció una notable influencia en varios renombrados periodistas y colaboradores de El Liberal sevillano, como su propio cuñado Chaves Rey, José Muñoz San Román o José Andrés Vázquez, quienes en más de una ocasión se proclamaron discípulos suyos. ${ }^{7}$

A aquella primitiva redacción de El Liberal también pertenecía Alfredo Murga, un hombre joven -contaba con unos 35 años hacia 1902- y sin embargo ya veterano periodista. Hombre muy culto y simpatizante también con el republicanismo, Murga había colaborado hasta entonces en diarios como El Porvenir, El Posibilista, en La Andalucía Moderna, El Comercio y en revistas como El Arte Andaluz y Miscelánea; en 1893 había sido además uno de los primeros redactores fichados personalmente por Peris Mencheta para la plantilla de El Noticiero Sevillano. Fue precisamente Alfredo Murga quien asumió la dirección de El Li-

6. En los años siguientes José Nogales llegó a publicar varias novelas (Mariquita León o El último patriota) y colaboraciones literarias en periódicos como La Ilustración Española y Americana, La Época, ABC, Nuevo Mundo, Blanco y Negro, Alma Española, etc. Fallecido en 1908, unos años antes una hermana suya llamada Pilar había contraído matrimonio con Manuel Chaves Rey, padre del periodista Manuel Chaves Nogales y sobrino éste por tanto de José Nogales.

7. Sobre la biografía de José Nogales véase especialmente Rodríguez Castillo, Ángel Manuel, Vida y obra de José Nogales, Huelva, Diputación, 2000. 
beral tras el rápido traslado a Madrid de José Nogales. Su dirección sin embargo tampoco duró muchos años, pues a partir de finales de 1908 una hemiplejía, que acabaría poco después provocándole la muerte, obligó a que de manera interina ocupase la dirección José García Orejuela, que hasta entonces había desempeñado el puesto de redactor-jefe. Éste, hombre también joven y de buena salud, falleció a su vez repentinamente de un ictus cerebral a finales de diciembre de 1909, con lo cual puede decirse que ser designado para el cargo de director de El Liberal de Sevilla parecía ser, al menos por aquellas fechas, el mejor medio de garantizarse un rápido tránsito a mejor vida: no en vano los tres directores con que había contado el diario desde su fundación no sobrevivieron a los primeros años del periódico.

Fue pues a finales de 1909 cuando José Laguillo asumió interinamente la dirección del periódico, a propuesta de sus compañeros de redacción y a pesar de su exigua y corta experiencia profesional. Como él mismo reconocería en sus Memorias, hasta entonces y durante la mayor parte de su vida, Laguillo no había sido otra cosa más que el hijo de una familia bien, acostumbrado a las comodidades que la buena situación económica de su clase le había permitido disfrutar. Un diletante bastante tímido y reservado, acostumbrado a iniciar carreras universitarias que rara vez terminaba (sí finalizó la de Magisterio) y que en realidad apenas se diferenciaba de otros tantos «señoritos» ociosos, como se decía en la época, más que por su interés por la lectura, que le llevaría a curiosear de forma autodidacta sobre mil temas y a intentar aprender el significado de las palabras en lenguas tan exóticas y, aparentemente tan poco prácticas en la España de finales del siglo XIX, como el amahara, el persa, el hebreo o el manchú.

Sin embargo, en torno a los treinta años y al tiempo que los ingresos y rentas familiares disminuían peligrosamente, Laguillo decidió sentar la cabeza, formalizar las relaciones con su novia (maestra nacional) y casarse. Fue entonces cuando, sin una profesión clara que le atrajese, salvo alguna en la que pudiera dar rienda suelta a lo que él mismo llamaba su manía literaria, comenzó a colaborar en La Iberia, un efímero diario de los canalejistas sevillanos; desaparecido éste y gracias a sus contactos logró entrar en 1903 como meritorio en la redacción del recién fundado El Liberal, con un modesto sueldo de cien pesetas mensuales. Seis años después y por mor de las circunstancias apuntadas, Laguillo iba a ser elevado al puesto de director del periódico, cargo en el que fue ratificado desde Madrid. Según su propio testimonio, «contaba yo entonces 39 años, y ni por pensamiento soñaba en direcciones ni en categorías, para lo que sabíame sin carácter, y lo que es más, sin estímulos. Pero, desde luego, me puse con celo a la obra, tomándole enseguida gusto, porque vi pronto cuánto desde el puesto podía 
hacerse en bien de Sevilla... ${ }^{8}$ Gusto y regusto evidentemente debió de cogerle al cargo, y eficaz al frente del mismo debió resultar su gestión para los propietarios del diario, pues a pesar del elevado índice de mortalidad de sus anteriores directores José Laguillo iba a permanecer al frente de El Liberal durante los veintisiete años siguientes. Toda una época de la Historia de España marcada por la larga y lenta descomposición de la Monarquía de Alfonso XIII, la Dictadura impuesta por aquel «cirujano de hierro» que creyó ser el general Miguel Primo de Rivera y la breve experiencia democrática de la Segunda República.

\section{Un diario de información independiente}

Desde 1910 y ya bajo la dirección de su joven director, El Liberal comenzó una etapa de expansión que le llevaría a convertirse en el diario de mayor circulación de Andalucía. Aunque los inflados datos de la Estadística de la Prensa Periódica de 1913 cifren su tirada en unos 28.000 ejemplares diarios, en realidad su distribución no debía superar los diez a quince mil ejemplares, por debajo de la de periódicos como El Noticiero Sevillano, todavía por esas fechas el diario más asentado e influyente en la capital andaluza. No obstante, el profundo «sevillanismo» de su director y la destacadísima atención prestada por El Liberal a la información local y provincial, convirtieron a este periódico no sólo en uno de los medios de comunicación más leído y apreciado por los sevillanos de comienzos de siglo, sino también en una fuente inapreciable de noticias sobre múltiples aspectos de la vida local de esa época.

Sin embargo, donde más se hizo notar la impronta de la dirección de Laguillo fue en el cambio de orientación de la línea ideológica mantenida hasta entonces por el diario. Y es que hasta 1910 El Liberal de Sevilla, conforme a la tendencia predominante en el trust de la Sociedad Editorial de España, a la cual pertenecía, había sido un periódico de un claro perfil progresista, simpatizante y atento a recoger en sus páginas las inquietudes, aspiraciones y demandas de los partidos y organizaciones situadas más a la izquierda del espectro político, incluso de aquellas situadas en el extrarradio de los estrechos márgenes impuestos por el sistema político de la Monarquía. Laguillo no dudó en referirse en sus Memorias a los ímprobos esfuerzos que tuvo que realizar para lograr, según sus palabras, «impersonalizar» al periódico, hasta entonces supuestamente «mediatizado por ciertas influencias, aunque estas no le sometían al vasallaje...».9 Aunque su decisión de acentuar la independencia e imparcialidad del diario no dejó de causarle algunos problemas, la apuesta pareció darle la razón. Como

8. Cfr. Laguillo, José, . Memorias..., p. 226.

9. Ibidem, pp. 230-232. 
él mismo escribió, independencia y autoridad en un órgano de información y publicidad forzosamente habría de traducirse en un buen negocio, sobre todo en una situación como la de comienzos del siglo XX en la que aún imperaba el criterio de que un periódico era «algo fatalmente adscrito a un hombre, un partido o una tendencia política...». ${ }^{10}$ El paulatino incremento de la tirada del diario $y$, con ello, la rentabilidad industrial para la empresa, explican que dos hombres con caracteres tan diferentes y contrapuestos como José Laguillo y Miguel Moya, el Diputado republicano y el presidente de la más importante empresa editora de España, mantuvieran un trato cordial y amistoso.

Desde 1919, sin embargo, la Sociedad Editorial de España, que ya unos años antes había tenido que desprenderse de El Noroeste de Gijón y de las ediciones de El Liberal en Barcelona y Bilbao, entró en una profunda crisis, acentuada por los efectos de una dura y prolongada huelga de periodistas en Madrid. De hecho, gran parte de los redactores, tipógrafos y administrativos de El Liberal abandonaron el periódico para fundar un nuevo diario, que pasó a llamarse La Libertad y que recogió al público obrero y de izquierdas que hasta entonces había constituido mayoritariamente la audiencia del diario madrileño. Unos meses después, el 19 de agosto de 1920, fallecía el propio Miguel Moya, hecho que precipitó la desaparición de lo que quedaba de su trust de prensa. ${ }^{11}$ A partir de enero de 1923 y tras varios meses de complicadas negociaciones, uno de los principales acreedores de la Sociedad Editorial, los industriales catalanes hermanos Busquets, suministradores de tinta a los periódicos de la cadena, se hicieron con la propiedad de la misma surgiendo así la denominada Sociedad Editora Universal, nacida con un capital de 1.500 .000 pesetas y 1.000 .000 de obligaciones en circulación. Curiosamente, como señalaron Seoane y Sáiz, eran ahora catalanes los propietarios del trust de prensa que «quince años antes había representado al núcleo más fuerte de hostilidad contra Cataluña en la prensa de Madrid». Amadeu Hurtado, abogado de los Busquets, futuro diputado a Cortes de ERC durante la Segunda República y encargado inicialmente de la gestión de la nueva empresa, tenía muy claro el objetivo de aquella operación: convertir a la Sociedad Editora Universal, constituida por El Liberal y el Heraldo de Madrid, El Liberal de Sevilla y Murcia, El Defensor de Granada y la revista La Moda Práctica, publicaciones que inicialmente integraron el nuevo trust, «en un instrumento para intervenir en la vida española, pensando en catalán...». ${ }^{12}$

10. Ibidem, p. 230.

11. Sobre todo ello puede verse con más detalle SEOAne, M. C. y Sáiz, M. D., Historia del periodismo, op. cit..., pp. 266-269.

12. Ibidem, p. 268. 
La lectura de las Memorias de Laguillo ofrece sobrado testimonio de que estos cambios en la empresa de la cual dependía El Liberal de Sevilla fueron cualquier cosa menos bien recibidos y acogidos por su director. No obstante, a comienzos de los años veinte El Liberal se había convertido ya en el principal diario de la capital andaluza. ${ }^{13}$ Lejos de aquella extrema proliferación característica de comienzos de siglo, a la altura de 1920-1921 el número de diarios sevillanos se había restringido a sólo cuatro: por orden de antigüedad, El Noticiero, El Correo de Andalucía, El Liberal y La Unión. Según las Estadísticas de la Prensa Periódica de 1920 y 1927, mucho más fiables que las de comienzos de siglo, la tirada de El Liberal en esos años osciló entre los 30.000 a 35.000 ejemplares diarios, datos estos que, con las salvedades que apuntaremos más adelante, vienen a corresponderse con los que figuran en la documentación interna del periódico, conservada en el Archivo de Salamanca. Con dos ediciones de mañana y noche, que mantenía desde su fundación, los talleres de El Liberal contaban con cuatro linotipias, máquinas de componer y dos rotativas, siendo 28 los trabajadores empleados en su imprenta y 6 los administrativos. El periódico publicaba habitualmente ejemplares de seis páginas, de 62 x 41 centímetros, costando a mediados de los años veinte 10 céntimos el precio del ejemplar y dos pesetas la suscripción mensual. Su redacción, compuesta por doce periodistas y que creció hasta contar con dieciséis miembros a comienzos de los años treinta, era la más nutrida de todos los diarios que por entonces se publicaban en Sevilla.

Con el paso de los años El Liberal había acentuado su carácter de diario independiente, que tan buenos dividendos y rentabilidad económica le había proporcionado a la Sociedad Editorial presidida por Moya. Aparte de la información nacional e internacional, suministrada telegráficamente por las agencias de noticias y objeto - de forma esporádica- de sesudos editoriales y artículos de opinión firmados por su director, en El Liberal de Sevilla predominaba ante todo y por este orden, la información local, provincial y regional, siendo célebres sus campañas y encuestas de opinión sobre muy variados temas, que el diario solía abordar bien en forma de entrevistas a determinadas personalidades o pidiéndole directamente a sus lectores que les hicieran llegar su parecer sobre algún asunto estimado de interés.

Aunque en lo publicado sobre El Liberal ha primado casi exclusivamente la labor de José Laguillo, debido a la riqueza de datos que proporcionan los apuntes contenidos en sus Memorias, lo cierto es que su línea editorial, el hacer del día

13. Según Antonio Checa, El Liberal de Sevilla y La Unión Mercantil de Málaga eran ya probablemente los diarios con mayor difusión en Andalucía durante estos años. Véase CHECA Godor, Antonio, Historia de la Prensa andaluza, Sevilla, Fundación Blas Infante, 1991, p. 193. 
a día del periódico y gran parte del éxito del mismo fueron el resultado de la labor desarrollada por un gran equipo de profesionales que iban a formar parte de la redacción de El Liberal hasta julio de 1936. A ellos se debe también, más que al propio Laguillo, el carácter progresista y avanzado que desprenden muchas de las páginas de El Liberal, sobre todo en comparación con el tono y enfoques profundamente conservadores habituales en el resto de los diarios sevillanos de los años veinte y treinta.

Buena parte del trabajo diario de El Liberal descansaba sobre el jefe de redacción, Diego Martín Núñez, un hombre joven que a comienzos de siglo, entre 1909 y 1912, había sido redactor del periódico republicano El Pueblo. Amigo personal de Diego Martínez Barrio y miembro del Partido Republicano Radical, Martín Núñez desempeñó en dicha organización los cargos de vocal de la junta municipal radical entre 1910-1911, secretario de actas del comité provincial y miembro de la junta radical del primer distrito en 1911. Durante los años de la Dictadura de Primo de Rivera continuó vinculado al republicanismo y entre 1930-1931 fue vocal de la junta municipal central del Partido Republicano Autónomo de Sevilla. Martín Núñez era incluso masón, pues en 1912 había sido iniciado con el nombre simbólico de «Gabroche» en la Logia Germinal de Sevilla, dirigida por Martínez Barrio, siendo exaltado al grado de compañero e ingresando en 1914 en la Logia Isis n. ${ }^{\circ}$ 350, de donde nacería poco después la poderosa Logia Isis y Osiris, impulsora del renacimiento masónico que se vivió en Andalucía durante los años veinte. Martín Núñez fue quien asumió la dirección de El Liberal de Sevilla en la primavera de 1936, tras la renuncia de Laguillo y tras rotularse el periódico como «Diario republicano de información». Aunque logró milagrosamente salvar la vida tras la sublevación militar del 18 de julio y la ocupación de la ciudad por las fuerzas de Queipo, Martín Núñez fue procesado por el Tribunal Especial para la Represión de la Masonería y el Comunismo, condenado a 12 años de prisión y depurado e inhabilitado para poder ejercer su profesión de periodista. ${ }^{14}$ En la posguerra tuvo que ganarse la vida como administrativo, trabajando hasta el final de su vida empleado para la empresa del cine Coliseo España.

Junto a Diego Martín Núñez, otros dos populares e influyentes redactores de El Liberal de conocidas simpatías republicanas fueron Agustín López Macías, cuya especialidad eran los reportajes, más conocido por su seudónimo de

14. Su expediente personal y el sumario de su procesamiento por el TERMC se conservan en el Centro Documental de la Memoria Histórica de Salamanca, sección Masonería, serie B, caja 347, expediente 10. Alguna carta con Martínez Barrio durante su etapa como director de El Liberal se conserva en la sección Político-Social, serie Valencia, caja 65, expediente 159. 
«Galerín»-del cual también se conserva en Salamanca alguna correspondencia con Martínez Barrio ${ }^{15}$-, y José Muñoz San Román, encargado de la información municipal. ${ }^{16}$ El resto de los componentes de la redacción de El Liberal eran Antonio Reyes, más conocido por «Don Criterio», especializado en la crítica taurina, aunque también desempeñaba las funciones de reportero en el Gobierno Civil, fallecido en abril de 1934; Joaquín López San Miguel, encargado de la información política; Arturo Otero Sánchez, al frente de la sección de deportes y secretario de redacción; y José Fernández de Villalta, especializado en sucesos. De recoger la información suministrada por las agencias de noticias, bien por telégrafo o por teléfono, se encargaban Emilio Gierts López y Antonio Jiménez Oliver, en el turno de noche, y Luis Arriaga y Antonio Márquez Prieto, en el de tarde. En la plantilla de El Liberal trabajaron también otros miembros de la familia Laguillo, como Teodomiro Laguillo Bonilla -hermano del director- que a finales de los años veinte se hizo cargo de la información de la Audiencia y de las traducciones de prensa extranjera; y Ricardo Laguillo Martín, que ingresó como meritorio y ayudante de los redactores Antonio Soto Repiso y José María Herrera ya en los años treinta, sustituyendo a Luis Rojas. Como fotógrafo trabajó siempre para El Liberal Cecilio Sánchez del Pando, posiblemente el mejor fotoperiodista sevillano de esta época. Colaborador también de El Heraldo de Madrid, las espléndidas fotografías de Sánchez del Pando, parte de cuyo archivo se conserva hoy en la Fototeca Municipal de Sevilla, se publicaron en afamadas revistas como Mundo Gráfico, Nuevo Mundo y Toros y Toreros, de Madrid; en La Hormiga de Oro, de Barcelona, o en La Unión Ilustrada, de Málaga. A partir de 1936 este fotógrafo logró continuar trabajando en el diario FE, convirtiéndose en buena medida -según Inmaculada Molina y Elena Hormigo- en el forjador de la imagen del Movimiento Nacional y en el fotógrafo oficial de la Sección Femenina en Sevilla. ${ }^{17}$

La documentación conservada en el Archivo de Salamanca nos permite conocer también el importe de las nóminas que cobraban los redactores que constituían la plantilla de El Liberal. En octubre de 1929 abonarles sus sueldos a sus

15. Centro Documental de la Memoria Histórica de Salamanca, sección Político-Social, serie Valencia, caja 49, expediente 172. En concreto se trata de una carta fechada el 19 de marzo de 1936, felicitando a don Diego por el triunfo electoral del Frente Popular y su anunciada elección como presidente de las Cortes.

16. Sobre López Macías ofrece algunos datos Arenas Posadas, Carlos, El libro de «Galerín», Sevilla, Diputación, 1984. Muñoz San Román colaboró también en algunas de las más importantes revistas gráficas de los años treinta, como Nuevo Mundo.

17. Véase sobre Sánchez del Pando, Molina, Inmaculada y Hormigo, Elena, Sevilla en blanco y negro, Madrid, Espasa-Calpe, 2000, pp. 74-76. En este libro se reproducen algunas de las más bellas imágenes captadas por la cámara de este afamado fotoperiodista. 
quince redactores le suponía a la empresa editora un gasto mensual de 5.000 pesetas, aunque sólo los honorarios del director, José Laguillo, representaban una quinta parte del total. Las diferencias eran muy notables, e iban desde las 1.000 pesetas que cobraba Laguillo a las 125 que constituían el sueldo del fotógrafo Sánchez del Pando, o la gratificación de 100 pesetas mensuales que recibía el meritorio Luis Rojas. La nómina del redactor jefe, Diego Martín Núñez, representaba justamente la mitad que la del director (500 pesetas). Entre los redactores mejor pagados del diario siempre figuró «Galerín», que pasó de cobrar mensualmente 450 pesetas en 1929 a 583 pesetas en vísperas de 1936. Durante los años treinta y a pesar de que la plantilla de El Liberal se redujo, bajando a catorce miembros, el coste de las nóminas de sus redactores no hizo sino crecer: en abril de 1933 ascendía a un importe de 6.100 pesetas mensuales y dos años más tarde, en enero de 1935, este concepto representaba un coste mensual de $6.983,30$ pesetas. Aunque todos los redactores vieron incrementados sus salarios durante los años treinta, el más beneficiado fue de nuevo el director de la publicación, José Laguillo, que pasó a cobrar 1.500 pesetas al mes; es decir, 500 pesetas más de lo que cobraba como sueldo un diputado a Cortes de la Segunda República.

\section{El Liberal durante la Dictadura de Primo de Rivera}

Los años veinte fueron sin duda los del crecimiento y consolidación definitiva de El Liberal de Sevilla. Aparte de su atención preferente a los asuntos sevillanos, El Liberal endureció en esas fechas su discurso pretendidamente regeneracionista e independiente y sus críticas a los políticos del sistema. Unos meses antes del golpe de Estado que acabaría encabezando el general Primo de Rivera y en un editorial de talante nada liberal, el periódico de Laguillo lanzó una durísima descalificación de la situación por la que atravesaba el país, del vergonzoso espectáculo que estaban ofreciendo los partidos con motivo de la preparación del encasillado y de la inutilidad de la casta gobernante:

«La degeneración de nuestra política justifica todas las formas de oposición y cualquier procedimiento que para exteriorizarse se quiera emplear. Cuando el Parlamento es un sepulcro y el régimen normal de libertad un motivo para que la democracia sólo resulte un irrisorio simulacro, hay que admitir con entusiasmo, aureolándolo con la esperanza, cuanto signifique noble rebeldía (...) No importa que se rebasen las lindes del constitucionalismo y las letras de las prescripciones estrictas...». ${ }^{18}$

18. El Liberal, Sevilla, 22-2-1923. 
No es extraño, por tanto, que El Liberal recibiese en septiembre de 1923 la llegada de la Dictadura si no con entusiasmo, sí al menos con una actitud de neutralidad algo más que benévola. En su opinión, la intervención de los militares no era sino «el corolario de una sistemática inhibición» y «un caso vulgar de intervención quirúrgica». ${ }^{19}$ Curiosamente, los comentarios de El Liberal y las opiniones de su director acerca de aquellos acontecimientos guardaron una gran similitud con los ofrecidos por los periódicos situados en la extrema derecha del espectro ideológico, como era el caso de El Correo de Andalucía, órgano de expresión de católicos y mauristas. ${ }^{20}$ En los días siguientes al triunfo del golpe los editoriales de El Liberal no se desviaron ni un ápice de la línea ya apuntada, expresando su confianza de que el régimen de dictadura que ahora se iniciaba sería capaz de regenerar al corrupto sistema político, sustituyéndolo por «la política de la seriedad y la sensatez; la política moderna, en la que actúan como pilotos los aptos y los especializados, los mejores, no las castas y las familias de profesionales oligarcas que, dueños de la impunidad, compatibilizaban la ambición y la ineptitud con la decadencia y los desastres de la Patria...». ${ }^{21}$ Incluso en una de esas piruetas ideológicas tan habituales en José Laguillo, el 16 de septiembre y en su primera plana El Liberal llegó a insertar un breve firmado por «Thales», en el que se alababa la íntima unión y el amor que el pueblo italiano sentía por su Duce, Benito Mussolini, afirmando que el régimen fascista no era simplemente el triunfo de una dictadura impuesta por la fuerza, sino «de la dictadura del sentimiento y del corazón de un pueblo, conquistados por la virtud del talento y por el afán de los pueblos de que los dejen vivir en paz y en justicia, como manda Dios...».22

La actitud, pues, de El Liberal ante el régimen nacido del golpe de Estado de septiembre de 1923 fue cuando menos contradictoria; una contradicción en la que el periódico iba a mantenerse inmerso en los años siguientes, pretendiendo nadar entre dos corrientes, reclamando en el terreno abstracto de las ideas y conceptos políticos la necesidad de un régimen que asegurase el predominio del poder civil y la necesaria reorganización de los elementos progresistas y liberales, pero mostrando igualmente su simpatía y su apoyo a la labor pretendidamente quirúrgica, modernizadora y regeneracionista impulsada por la

19. El Liberal, Sevilla, 15-9-1923.

20. La actitud de los diarios sevillanos ante el golpe de estado de Primo de Rivera ya tuvimos la ocasión de analizarla en Álvarez del Rey, Leandro, Sevilla durante la Dictadura de Primo de Rivera: la Unión Patriótica (1923-1930), Sevilla, Diputación, 1987, pp. 66-70.

21. El Liberal, Sevilla, 16-9-1923.

22. El Liberal, Sevilla, 16-9-1923. 
Dictadura. ${ }^{23}$ Así, la decisión de Primo de Rivera de impulsar y hacer realidad a cualquier trance aquel aletargado proyecto de Exposición Iberoamericana, verdadera debilidad de las aspiraciones «sevillanistas» de José Laguillo, hizo que su periódico se convirtiera durante los años veinte en el más fiel portavoz de los organismos designados por la Dictadura para llevar a cabo tal empresa. El Liberal siempre defendió la necesidad de acatar las decisiones adoptadas por el comité encargado de llevar a cabo el proyecto de Exposición, utilizando un tono conciliador e interpretando que todo lo que afectase negativamente al comité, iba en perjuicio de la Exposición. No es extraño, pues, que El Liberal acabara convirtiéndose en el portavoz oficioso del comité y de las autoridades de la Dictadura en Sevilla. ${ }^{24}$

Dicha actitud ciertamente no dejó de proporcionarle algunos disgustos al propio Laguillo, sobre todo cuando en septiembre de 1925 El Noticiero y El Liberal decidieron iniciar al unísono una campaña en contra de los patronos de la Unión Comercial, a quienes acusaron sin veladuras de corrupción, de estar lucrándose a costa de las obras de la Exposición y de pretender convertirse en los nuevos amos y caciques de Sevilla. En unos durísimos artículos el periódico arremetió contra los principales prohombres de la Unión Comercial, denunciando su estrategia de acoso y asalto al municipio. ${ }^{25}$ Pero La Unión, el periódico portavoz de la Unión Comercial, devolvió el golpe con saña, publicando un artículo titulado «El Liberal chupa del bote $»^{26}$ en el que se denunciaba que dos hermanos del director de El Liberal, Emilio y Teodomiro Laguillo, figuraban como empleados del comité de la Exposición, y que el propio José Laguillo, aparte de ser miembro de su comisión permanente, había sido nombrado secretario de la junta del Colegio Mayor Hispano-Americano, cobrando 1.000 pesetas al mes por dos horas diarias y en compensación por los favores prestados por su periódico. Días después Laguillo presentó su dimisión como miembro de la comisión permanente de la Exposición. No obstante, en junio

23. El periódico, de nuevo a través de un editorial de su director, no dudó en saludar al nuevo régimen primorriverista con estas comprensivas palabras: «Estamos frente a un nuevo régimen político (...) No incurramos en el error de clasificar movimientos como éste. Dictadura o no da igual. En una vergonzosa e hipócrita dictadura mansa vivíamos... Es secundario el instrumento del milagro». Cfr. Laguillo, J., «Ante el nuevo régimen. Acción y opinión. Hacia otras normas», El Liberal, Sevilla, 16-9-1923.

24. Véase Lemus López, Encarnación, La Exposición Ibero-Americana a través de la Prensa (19231930), Sevilla, Mercasa, 1987, en especial p. 18.

25. Lugar citado.

26. La Unión, de Sevilla, 15 y 16-9-1925. Véase también Lemus López, E., La Exposición..., op. cit.,pp. 74-75. A este incidente también se refiere José Laguillo, lógicamente con una interpretación diferente, en algunos pasajes de sus Memorias. 
de 1927, tras un duro enfrentamiento entre el Ayuntamiento y José Cruz Conde, comisario regio y gobernador civil, concluido con la destitución masiva de la corporación municipal, Laguillo no tuvo inconveniente en aceptar ser nombrado concejal por el todopoderoso Cruz Conde, cargo en el que se mantuvo hasta el mes de febrero de 1930, tras la dimisión de Primo de Rivera y el final de su Dictadura.

Así pues, en modo alguno puede aceptarse la idea de que El Liberal fue, en la Sevilla de los años veinte, el periódico más crítico con la Dictadura y el único diario sevillano que luchó por la llegada de la República, afirmaciones éstas que denotan un profundo desconocimiento. El diario de Laguillo ni siquiera protestó cuando en abril de 1926 la publicación satírica Sevilla en Broma, que todos los años editaba por su cuenta el redactor más popular de su plantilla, Agustín López Macías, «Galerín», fue secuestrada por el pecado de incluir un artículo en el que ridiculizaba, en tono humorístico, a la Unión Patriótica y la labor del comisario regio y gobernador. ${ }^{27}$ Tampoco nos consta que el diario dirigido por Laguillo protestase cuando en mayo de 1929, en vísperas de la inauguración de la Exposición Iberoamericana, Primo de Rivera ordenó multar con 50.000 pesetas a un periódico de su propia empresa editorial, el Heraldo de Madrid, por difundir noticias que iban «contra el interés nacional y los intereses morales y económicos de Sevilla...». ${ }^{28}$

Ahora bien, en el terreno de lo puramente teórico y especulativo, sí es cierto que El Liberal defendió en varias ocasiones la necesidad de una resurrección del espíritu liberal. Ya en marzo de 1924, desde las páginas del diario se sugirió la conveniencia de constituir un nuevo partido «en cuyo caudal refluyeran variadísimos aportes de todas las direcciones de la izquierda, desde las más avanzadas a las más moderadas...». ${ }^{29}$ En enero de 1925 El Liberal volvió a recurrir a una de sus ya tradicionales encuestas de opinión -llamadas ahora «plebiscitos»- planteando a sus lectores una serie de preguntas sobre la futura transformación política del país, en qué normas habría de inspirarse la presumible reforma de la Constitución, cómo habrían de ser las nuevas Cortes, etc., iniciativa ésta que incluso llegaría a ser comentada favorablemente por el periódico El Socialista. Los resultados de esta encuesta fueron realmente curiosos, pues aparte de la unáni-

27. El Liberal se limitó a reproducir la nota oficiosa del gobernador justificando la recogida de la edición del Sevilla en Broma, si bien unos días más tarde publicó una carta de «Galerín» contestando a la nota de Cruz Conde. Véase El Liberal, de Sevilla, 24 y 26-5-1926.

28. El origen de esta enorme sanción gubernativa fue un artículo titulado «De Sevilla, para los turistas», dando cuenta de una supuesta riña en la capital andaluza de la que habría resultado un herido grave. Véase La Unión, de Sevilla, 9-5-1929.

29. Véase «Los nuevos partidos. El democrático popular», El Liberal, de Sevilla, 19-3-1924. 
me y enérgica condena de los lectores al régimen antiguo, «basado en absurdos y grotescos cacicatos», una mayoría abrumadora de los que decidieron responder a la encuesta se declararon a favor de unas Cortes Constituyentes, elegidas por sufragio universal directo y que llevasen a cabo un reforma amplia y radical «a tono con las líneas que marca la democracia universal y las normas en vigor en los países a la cabeza del parlamentarismo...». Más inquietante era aún una de las conclusiones que se extraían de aquel sondeo de opinión, conclusión a la que El Liberal procuró restarle importancia posiblemente para poder eludir el filtro de la censura. Según las cuidadas palabras utilizadas por el diario, «finalmente, una minoría, que representa aproximadamente el treinta y cinco o cuarenta por ciento de las respuestas recibidas, se ha declarado franca y abiertamente por la República...». Si esto es cierto, si a la altura de comienzos de 1925, en uno de los momentos de mayor popularidad de la Dictadura, aproximadamente un cuarenta por ciento de los encuestados por un periódico se declaraban ya abiertamente partidarios de la República, lo que se ha escrito comúnmente sobre la consolidación del sentimiento republicano en España tendría que ser revisado en profundidad. Según esto, la viabilidad de una alternativa política a la Monarquía no puede situarse sin más en 1930-1931, los meses de los grandes errores y del colapso monárquico, sino que habría que retrasarlo, a juzgar por los resultados de esta encuesta de El Liberal, al menos a mediados de los años veinte, fecha ésta en la que un amplio sector de la opinión pública -al menos de la opinión pública andaluza- no parecía ver ya otra salida a los problemas políticos del país que la instauración de una República, democrática y parlamentaria. ${ }^{30}$

Ciertamente, a José Laguillo le crecían los republicanos hasta en su propia casa, pues el 11 de febrero de 1926, con motivo de un acto celebrado en la Tertulia Republicana en conmemoración del aniversario de la Primera República, el redactor-jefe de El Liberal, Martín Núñez, ocupó un lugar destacado en la mesa presidencial, y «Galerín» publicó un escrito -solicitando previamente la benevolencia del «Hermano Censor»- en el que daba cuenta de su asistencia al mismo, en calidad de republicano, describiendo con todo lujo de detalles el desarrollo del acto, la asistencia de más de doscientas cincuenta personas y la actuación de

30. El contenido del cuestionario propuesto por El Liberal a sus lectores apareció publicado el 17 de enero de 1925, bajo el título «La próxima transformación política». En los días siguientes el diario reprodujo algunas de las respuestas recibidas; los resultados de la encuesta fueron dados a conocer unas semanas después, bajo el siguiente epígrafe: «Una consulta al estado llano nacional. El resumen de nuestro plebiscito», El Liberal, de Sevilla, 9-2-1925. La buena acogida de El Socialista en El Liberal, 14-2-1925. 
una orquesta, que interpretó «La Marsellesa» y el «Himno de Riego». ${ }^{31}$ Sensible sin duda a estos nuevos aires de la opinión pública, José Laguillo, utilizando el pseudónimo de «Tipsius», comenzó a publicar en estas fechas una serie de artículos preconizando unas bases a las que, según él, debería acomodarse la renovación del espíritu liberal, factor principal para que pudiera operarse la renovación de España. Todo ello, claro está, situado siempre en el elevado plano de las aspiraciones metafísicas, tan caras al director de El Liberal. ${ }^{32}$

El año de la Exposición, a pesar de la dura competencia que iba a suponer para los diarios locales la aparición de la edición sevillana del $A B C$, el diario de los Luca de Tena, encontró ya a El Liberal erigido en el principal medio de comunicación de una capital convertida casi en noticia permanente, a raíz de los fastos relacionados con la celebración de aquel Certamen. Pocos periódicos andaluces podían presumir por entonces de la tirada y distribución de El Liberal de Sevilla, aunque ésta variaba ostensiblemente incluso en un mismo mes. Según los datos conservados en el Archivo de Salamanca, la tirada de El Liberal en noviembre de 1929 osciló entre los 23.240 ejemplares distribuidos el 24 de dicho mes (en una edición de seis páginas) y los 36.405 ejemplares del 2 de noviembre, fecha ésta en la que salió con una edición de 8 páginas. Es decir, una diferencia en un mismo mes de 13.000 ejemplares.

Aun así, no hay duda de que la publicación de la edición sevillana de El Liberal seguía constituyendo un buen negocio, algo que a buen seguro debieron apreciar los dueños de la Sociedad Editora Universal, los hermanos Busquets. Según un informe de fecha algo posterior, elaborado por el gerente de El Liberal, imprimir unos 35.000 ejemplares del periódico de 8 páginas representaba -nóminas del personal aparte- un gasto corriente de aproximadamente 375 pesetas diarias, de las cuales el concepto de mayor envergadura era el correspondiente a los 400 kilos de bobinas de papel necesarias para la impresión, a un coste de 0,60 céntimos el kilo, lo cual representaba un gasto de 240 pesetas. Sin embargo, los ingresos por publicidad superaban ampliamente dicho gasto, pues por anuncios insertados en la plana general entera se obtenían 440 pesetas de ingresos;

31. Véase «Por las ideas liberales. Anoche se celebró un acto de gran trascendencia política en la Tertulia Republicana. Se inicia la unión de las fuerzas democráticas sevillanas», El Liberal, de Sevilla, 12-2-1926.

32. Los artículos firmados por «Tipsius», uno de los pseudónimos de Laguillo, sobre este asunto fueron los siguientes: «Por la unión de las izquierdas. La renovación del espíritu liberal. Proyecto de unas bases prácticas»; «El espíritu liberal, factor principal de la renovación de España» y «La concentración del espíritu liberal». Todo ello en El Liberal, de Sevilla, 27-2 y 2 y 9-3-1926. Periódicamente Laguillo volvió a insistir sobre el tema en otros artículos aparecidos en los años siguientes, algunos sin firmar pero todos con su inconfundible estilo. 
280 pesetas por las cuatrocientas líneas de «reclamos» y otras 315 pesetas por las aproximadamente trescientas líneas de «entrefilete» y otros anuncios que se insertaban en cada ejemplar, de lo cual resultaban unos ingresos diarios por publicidad de 1.035 pesetas. Descontado el importe de gastos corrientes (375 pesetas), resultaba un beneficio líquido diario de 660 pesetas por cada ejemplar de 8 páginas. Lógicamente, a este beneficio había que restarle los gastos de nóminas, distribución, reparación de maquinaria, luz, etc., pero aún así queda claro que El Liberal de Sevilla era una empresa muy rentable para los accionistas de la Sociedad Editora Universal, razón posiblemente por la cual el director y la plantilla del diario vieron incrementadas considerablemente sus retribuciones a partir de comienzos de los años treinta.

\section{Los años treinta. Un diario tardíamente republicano}

El hundimiento de la Monarquía y la proclamación de la Segunda República en abril de 1931 fueron recibidos de forma entusiasta en las páginas de El Liberal, aunque no quepa decir lo mismo del ánimo de su director. Algo comprensible si tenemos en cuenta que Laguillo no duda en calificarse a sí mismo, en sus Memorias, como un monárquico convencido, por educación, ascendientes y gustos íntimos. ${ }^{33}$ Así pues, el entusiasmo y acatamiento al nuevo régimen republicano que dejaron traslucir las páginas de El Liberal a partir de abril de 1931, eran más un reflejo del parecer de algunos de los principales redactores del diario que del propio director de la publicación.

No obstante, aunque difícilmente El Liberal puede adjetivarse como un diario de «izquierdas» en la Sevilla de la Segunda República, el periódico llegó a parecerlo, pero más que nada por contraposición con el rancio conservadurismo a ultranza que destilaban el resto de sus colegas. Por ejemplo, a comienzos de 1933, y una vez desaparecido El Noticiero Sevillano, hasta entonces decano de la prensa hispalense, El Liberal siguió siendo el único diario que continuó incluyendo en su sección de agenda las notas, avisos y comunicados enviados por las organizaciones republicanas y obreras, unas notas cuya inserción -incluso pagando las tarifas publicitarias-, por regla general y especialmente en períodos electorales rechazaban insertar de plano el resto de los periódicos sevillanos. Con motivo de la campaña electoral de finales de 1933, un diario con fama de liberal -el $A B C$ - llegó incluso a insertar un comunicado en el que decía que «aun respetando todas las ideas», no estaba dispuesto a acoger ni apoyar en sus columnas ninguna nota de propaganda electoral que no se refiriera a las derechas

33. Cfr. Laguillo, José, Memorias..., pp. 207-208. 
unidas. Curiosa manera ésta de respetar todas las ideas. ${ }^{34}$ Ante este panorama estaba claro que el único diario que podía leer en Sevilla alguien que no fuera de derechas $-\mathrm{y}$, a tenor de los resultados electorales, está claro que la mayoría de los sevillanos nunca se identificaron con esos partidos- era El Liberal.

En los años de la Segunda República El Liberal se pregonó insistentemente como el periódico de mayor circulación en Andalucía, con una tirada normal diaria superior a los 50.000 ejemplares, dato que en líneas generales también corrobora la documentación conservada en Salamanca. Con una plantilla compuesta por 16 redactores en 1933 (reducida a 14 dos años después), cuyas nóminas suponían mensualmente un coste de 6.100 pesetas; 6 administrativos (2.050 pesetas mensuales); 39 repartidores (3.618 pesetas) y 23 empleados de su imprenta, compuesta por un regente, un corrector, un ajustador, un probero, un fundidor, 9 linotipistas, 4 cabeceros, 2 ayudantes mecánicos, 2 encargados de los anuncios y 1 aprendiz, cuyos sueldos mensuales alcanzaban la cifra de 8.619 pesetas, El Liberal había logrado alcanzar una tirada realmente excepcional para un periódico de provincias, hecha realidad gracias también a los 230 corresponsales y distribuidores con que contaba ya en 1932. En localidades de la provincia de Sevilla como Alcalá de Guadaira, Carmona, Dos Hermanas, Écija, Morón o Utrera, El Liberal vendía diariamente entre 400 y 600 ejemplares, y su distribución era también muy importante en las provincias de Huelva, Cádiz y Córdoba. Tan sólo en media docena de localidades onubenses (la propia capital, La Palma, Ayamonte, Isla Cristina, Nerva y Riotinto), El Liberal vendió en mayo de 1932 una media cercana a los 2.000 ejemplares diarios.

Este éxito del diario dirigido por Laguillo fue calurosamente refrendado por la décima junta general de accionistas celebrada por la Sociedad Editora Universal en Madrid, a finales de febrero de 1933. En la Memoria de la citada junta se hizo constar expresamente la siguiente mención: «Sevilla ha sido, sin duda alguna, la población de España en que más duras luchas se han reñido, y, sin embargo, de El Liberal de Sevilla decimos con satisfacción que ha sido combatido por distintos extremismos, probándose así su equidistancia y elevado espíritu de justicia social. Y como la razón se impone, El Liberal de Sevilla ha logrado rebasar en su circulación en más de 10.000 números la media normal de tirada de años anteriores...». La Sociedad Editora Universal, presidida por Manuel Busquets y que englobaba a los periódicos El Liberal de Madrid, de Sevilla y de Murcia, el Heraldo de Madrid y El Defensor de Granada, obtuvo aquel año unos ingresos de explotación cifrados en 7.323.957,37 pesetas, alcanzando los beneficios la res-

34. Véase «La próxima contienda electoral», ABC de Sevilla, 15-10-1933, p. 23. 
petable cifra -para la época- de 292.290 pesetas. Buena parte de ese superávit era atribuible al crecimiento sostenido de El Liberal de Sevilla. ${ }^{35}$

Sin embargo, fue por estas fechas cuando Laguillo decidió presentar por primera vez su dimisión al frente del periódico que llevaba dirigiendo desde hacía ya veinticuatro años. Las razones de su decisión hay que buscarlas, aparte del cansancio al que alude en sus Memorias, en su incompatibilidad esencial con la República y con los encargados de dirigir la política municipal en Sevilla: los republicanos de Martínez Barrio. Laguillo además, tras el fracasado golpe de Estado de Sanjurjo de agosto de 1932, se vio envuelto en aquel proceso que el Ayuntamiento republicano-socialista de Sevilla decidió iniciar contra los ex concejales de la Dictadura, pretendiendo imputarles la responsabilidad de las deudas de la Exposición y la situación de ruina financiera en que se hallaban las exhaustas arcas municipales. Aunque tal proceso se sobreseyó sin ninguna consecuencia, en su imaginario particular Laguillo llegó incluso a forjarse la creencia de que él había llegado a convertirse en un perseguido de la República, debido a su pertenencia a aquella dócil corporación municipal designada en 1927 por Cruz Conde: «ello me condujo -escribió en sus Memorias-al procesamiento cuando, llegada la República, todo aquel Ayuntamiento fue encartado. Un proceso por asistir a dos o tres cabildos no es poco...». ${ }^{36}$ Ensimismado en su idílica ensoñación de lo que habían sido los «felices» años veinte, Laguillo continuó hasta el final de sus días intentando justificar su actitud durante los años de la Dictadura, afirmando que «yo accedí a ostentar la concejalía no por gusto, sino porque la corporación carecía de carácter político, porque había que terminar la obra de la Exposición, porque en una palabra aceptaron el cargo directores y propietarios de los otros periódicos...». ${ }^{37}$ El hecho de que más de treinta concejales de aquella corporación municipal de la que él formó parte pertenecieran a la Unión Comercial, esa asociación de patronos aspirantes a caciques a la cual tan duramente había fustigado su propio diario, no era razón bastante para que Laguillo advirtiera el carácter político que indudablemente tuvo su decisión de aceptar aquel nombramiento de concejal. Incluso el diario La Unión, el periódico de los patronos al servicio ahora de los carlistas, tuvo que recordarle sus ditirámbicas alabanzas a la gestión de la Dictadura, y el hecho -que no hemos podido comprobar- de que El Liberal llegase a pedir un marquesado para recompensar los méritos de Cruz Conde, de aquel ex gober-

35. Cfr. Sociedad Editora Universal, Memoria presentada a la Junta General de Accionistas celebrada en Madrid el día 28 de febrero de 1933, Madrid, Gráficas Reunidas, 1933, p. 6.

36. Véase Laguillo, José, Memorias..., p. 234. No es cierto tampoco que, como afirma Laguillo, todos los directores y propietarios de periódicos aceptasen ser nombrados concejales.

37. Lugar citado. 
nador y comisario regio caído en desgracia antes incluso de la proclamación de la República. ${ }^{38}$

Tras presentar su dimisión ante el presidente de la Sociedad Editora Universal, trasladándose a tal efecto a Madrid, Manuel Busquets logró convencer al director de El Liberal para que reconsiderase su decisión y se tomase un descanso de seis meses, iniciando Laguillo una larga temporada de vacaciones en Portugal. De hecho, durante la mayor parte de 1933 quien dirigió El Liberal de Sevilla fue Arturo Mori, un periodista de origen catalán, antiguo amigo de Lerroux, enviado ex profeso desde Madrid. ${ }^{39}$ Pero el giro a la derecha que en la trayectoria de la Segunda República supusieron las elecciones de finales de 1933 y el ascenso de la CEDA dirigida por Gil Robles, tranquilizaron lo suficiente a Laguillo para decidirse a retomar desde comienzos de 1934 la dirección de El Liberal sevillano. Poco después el periódico varió levemente su formato, adoptando desde entonces una apariencia muy similar a la del Heraldo y El Liberal de Madrid, gracias a la adquisición de una máquina de la marca Koenig \& Bauer, capaz de imprimir doce páginas por ejemplar. ${ }^{40}$

Con Lerroux en el Gobierno y la CEDA de Gil Robles marcando el ritmo y los tiempos de la política revisionista aplicada durante el bienio de centroderecha, Laguillo no tuvo inconveniente en mantenerse al frente del diario que venía dirigiendo desde la ya lejana fecha de 1909. Consta sin embargo, por la correspondencia conservada en Salamanca entre el administrador de El Liberal de Sevilla y el gerente de la Sociedad Editora Universal, que desde 1935 el diario experimentó una considerable bajada en su tirada y una preocupante disminución de las ventas, un hecho que el responsable de la edición sevillana achacaba al aumento del precio de los periódicos recientemente autorizada por el Gobierno, cuyos resultados calificaba de deplorables. En Sevilla, además, durante el verano muchos suscriptores decidieron darse de baja por marcharse fuera de la capital o por trasladarse al campo, reclamados por las faenas agrícolas. Según el citado administrador, a esta difícil situación venía a sumarse la competencia desleal puesta en práctica por el diario La Unión, el crecido portavoz de los carlistas -su director, Domingo Tejera, había sido elegido diputado a Cortes por Sevilla en noviembre de 1933-, quien estaba ofreciendo a los corresponsales de prensa en los pueblos comisiones por nuevos suscriptores a su diario, rompiendo así un acuerdo interno respetado por el resto de los diarios sevillanos. El administrador solicitaba a la gerencia autorización para poder editar al menos dos días a la

38. Véase «Cock-tail sevillano. El Liberal, con censura eclesiástica», La Unión, de Sevilla, 102-1932, p. 4.

39. Cfr. Laguillo, José, Memorias..., p. 319.

40. Véase. «Grandes reformas de El Liberal», El Liberal, de Sevilla, 28-11-1933. 
semana ejemplares de 16 páginas, intentando así, por la vía de los ingresos por publicidad, compensar la reducción de ventas y beneficios. ${ }^{41}$

Sin embargo, lo que le decidió a José Laguillo a abandonar definitivamente la dirección de El Liberal no fueron problemas de índole económica, sino el triunfo electoral del Frente Popular en las elecciones de febrero de 1936. Ello y la decisión, adoptada por los propietarios de la Sociedad Editora Universal, de que a partir de abril de 1936 -cinco años después de la proclamación de la República- El Liberal de Sevilla suprimiera de su cabecera el rótulo de «Diario independiente» para sustituirlo por el de «Diario republicano de información». Aquello fue ya demasiado para aquel nostálgico de la Monarquía que era don José Laguillo. Según su propio testimonio, en un abrir y cerrar de ojos «El Liberal cambió de fisonomía. Limpio de mis escrúpulos de independencia, adoptó otros rasgos. Impuesto por la consigna de Madrid, titulose órgano del partido republicano. Prescindió de la información religiosa. Recargó la nota radical. Plasmó en sus páginas el más flamante izquierdismo... . ${ }^{42}$

Detrás de aquel cambio de rumbo Laguillo creyó percibir algo más temible aún que esa siniestra mano de los masones de la que hablaba constantemente la propaganda de las derechas: no, el peligro estaba en Cataluña, en una Cataluña contemplada como la terrible enemiga de España. Según sus palabras: «entonces se vio claro, por las campañas de sus periódicos de Madrid, que las personas que regentaban la Sociedad Editora no eran ya catalanes, sino catalanistas que se quitaban la careta, y que, del Ebro para acá, consideraban a España como enemiga...». ${ }^{43}$ Es decir, que según Laguillo, el hecho de que después de cinco años de República un diario decidiera por fin declararse republicano no era sino una prueba más de esa siniestra conjura internacional que amenazaba con destruir a España, con romper a España, convirtiendo a sus periódicos, según él, en «furibundos valedores de las doctrinas más exaltadas, amenaza terrible de la tranquilidad de la Patria... verdaderos seudo-marxistas, convivientes morales del incipiente seudocomunismo que comenzaba a contender con sus planes siniestros...». ${ }^{44}$

Ciertamente, párrafos como éstos denotan que Laguillo no era ya el periodista adecuado para dirigir un diario republicano en la España de 1936, y también

41. La correspondencia a la que nos referimos, correspondiente a los años 1934-1935 y que ofrece multitud de datos acerca de la gestión y vida empresarial de El Liberal sevillano, se conserva en el Centro Documental de la Memoria Histórica de Salamanca, sección PolíticoSocial, serie Madrid, Caja 1637.

42. Cfr. Laguillo, José, Memorias..., p. 322 y ss.

43. Lugar citado.

44. Sigue diciendo José Laguillo que «al apreciar el catalanismo separatista de tales catalanes, yo, un mes después de las elecciones, en marzo, rotundamente dimití...». 
que posiblemente hacía años que había dejado de ser el hombre adecuado para dirigir un periódico simplemente liberal. Tras su dimisión irrevocable asumió la dirección su hasta entonces jefe de redacción, Diego Martín Núñez, republicano y masón. En el mes de abril El Liberal saludó con grandes caracteres tipográficos, rara vez utilizados por este diario, la triunfal visita a Sevilla de su paisano, Diego Martínez Barrio, llegado como presidente interino de la Segunda República y acompañado por Lluís Companys, presidente de la Generalitat de Cataluña, y de Manuel Blasco Garzón, ministro de Comunicaciones del Gobierno del Frente Popular.

Pocas ocasiones tuvo El Liberal de Sevilla de volver a exteriorizar así su recién estrenada condición de órgano periodístico identificado con la República, pues unos meses después, en julio de 1936, un golpe de Estado arrasó su redacción y acabó con su historia; y con ella y durante los cuarenta años siguientes con cualquier atisbo de lo que había sido hasta entonces la independencia y la libertad de prensa en España. 